\title{
CLIMATE CHANGE ADAPTATION IN SERBIA: THE ROLE OF INFORMATION NETWORKS Aleksandra STUPAR*, Vladimir MIHAJLOV*
}

Received: 14.05.2014; Final Text: 30.12.2015

Keywords: Global warming; climate change adaptation; information networks; city; environmental upgrading.

\section{INTRODUCTION}

The importance of problems caused by global warming and increased GHG emissions have been recognized by the international community which responded through a growing number of studies and policies dealing with climate change prevention, mitigation and adaptation. Although these attempts have traced a path to positive and necessary improvements of our environmental awareness and behaviour, their application and effects have been conditioned by numerous contextual determinants. The situation is particularly complex in urban areas, which are labelled as major consumers of produced energy and significant contributors to GHG emissions (IEA, 2008). However, cities simultaneously represent generators of various solutions for environmental problems and risks which transpire from urban areas via information networks - transmitting knowledge, exchanging practices and creating new environmental trends (Bulkeley, 2010; EEA, 2012; UN-Habitat, 2011; World-Bank, 2010).

The European perspective on climate change has been defined by international documents, national legislation, policies and numerous initiatives originating from grassroots movements. The European Environmental Agency (EEA) emphasizes the importance of an integrated approach to environmental challenges and suggests four complementary approaches targeting mitigation of impacts, adaptation to expected changes, prevention of environmental harm and development of social and ecological resilience (EEA, 2015). The shift to green economy is confirmed as the highest development aim and additionally elaborated by several recommendations, including a better integration of environmental issues into policies and their full implementation; a necessity of future-oriented investments; support and diffusion of technological and social innovations; and the improvement of knowledge base (EEA, 2010; EEA, 2015).

Obviously, establishing a balanced relationship between environmental policies, economic efficiency, technological upgrading and behavioural 
change is one of the main challenges of our epoch, while availability, diffusion and exchange of information/knowledge represent a keyreinforcement of a green transition in economy and society.

The importance of information networks becomes even more visible in societies exposed to severe economic, social and environmental problems and limitations, caused by sensitive local circumstances. The case of Serbia, which is the focus of this article, reveals challenges generated after more than two turbulent decades of recent history, marked by the gradual breakup of Yugoslavia (1991-2000), international economic sanctions (19921996), civil wars on the parts ex-Yugoslavia, internal political conflicts and a general social and economic crises. Since democratic changes in 2000, Serbia has been adjusting its legislation framework and development imperatives with the demands of the European Union, simultaneously including environmental issues. The changes have been visible on institutional (governmental) and non-institutional (non-governmental) level, while information networks have been recognized as an important element of communication with the public.

Considering all these specificities, the article provides a review of detected practices related to the use of information networks in climate change adaptation on both global and local levels, stressing the possible benefits and limitations in the context of Serbia. The first part of the article introduces a global background of the problem of climate adaptation, summarizing major environmental trends, research problems and policy responses, and emphasizing the relationship between climate change and urban(ized) environment. The second part is dedicated to the case of Serbia, focusing on three aspects - general condition of the environment, the legal framework and the perception/recognition of urban context and its environmental effects in recent development documents. The third part is focused on the relation between information networks, built environment/cities and climate change, providing an overview of global trends and the Serbian context, while possible improvements of detected local weaknesses are given in the concluding part.

The article is based on the review of key literature, major international agreements and national laws, development strategies and search on the World Wide Web. Due to the multidisciplinary character of the analysed problem the selected bibliography and internet resources are related to three basic topics (targeting both global and local level) - the impact of climate change; adaptation and mitigation strategies/policies; and the role of information networks in contemporary society. Internet based search was directed to three thematic areas of climate adaptability - human behaviour, ecological awareness and general efficiency, considering the anticipated and achieved impact/audience and the mode of use.

The main part of the article originates from an ongoing research project, titled "Studying climate change and its influence on the environment: impacts, adaptation and mitigation", which has been funded by the Ministry of Education and Science of the Republic of Serbia within the framework of integrated and interdisciplinary research for the period 2011-2016. For the project, researchers from 39 research institutions within the country (institutes, universities, Serbian Academy of Science and Arts) were gathered and the majority of expected results are supposed to rely on the application on new technologies and information networks in the process of monitoring environmental conditions and risks, collecting and processing data, modelling, forecasting, optimisation of resources, 
education, behavioural changes and knowledge dissemination. The researchers from the University of Belgrade-Faculty of Architecture have focused on several specialised topics dealing with urban and rural development in shifting climate conditions - from strategies/policies and models of spatial development, to sectoral challenges and selected case studies. The overall results of the project will be summarized and published on the web site of the project (Istraživanje klimatskih promena $i$ njihovog uticaja na životnu sredinu: praćenje uticaja adaptacija i ublažavanje www.cleniam.rs - currently under construction). This will enable further dissemination of knowledge and provide links to published monographs, articles and conference papers produced after the conclusion of major research phases. Following the key relationship presented in this article (climate change-environment/cities-information networks), it is important to notice that there are currently several projects financed by the Ministry of Education and Science of the Republic of Serbia, oriented towards different aspects of climate change, and the researchers from the University of Belgrade - Faculty of Architecture (including the author of this paper) simultaneously participate in the project entitled "Spatial, Environmental, Energy and Social Aspects of Developing Settlements and Climate Change - Mutual Impacts", whose data base was also used in this article. Therefore, it could be said that all these projects support recommendations of the EEA related to the improvement of the knowledge base and the introduction of social and technological innovations in the process of climate adaptation.

\section{THE CHALLENGE OF CLIMATE CHANGE: THE GLOBAL BACKGROUND}

According to the analysis of the Intergovernmental Panel on Climate Change, global warming has been mainly caused by anthropogenic factors, especially since the beginning of the Industrial revolution and intensified urbanisation (IPCC, 2007a). Identified as the ultimate risk multiplier both for societies and ecosystems (IPCC, 2012; Roaf et al. 2005), the process of climate change has generated global fear (Hulme, 2008), which is further amplified by extreme weather events, natural disasters and the anticipated intensification of negative trends during the 21st century (IPCC, 2007a). This condition has influenced urgent decisions embedded in various international documents, while a number of wide-ranging proposals have been created as a result of undertaken projects and initiatives focusing on the prevention of temperature growth beyond projected limits of $+2^{\circ} \mathrm{C}$ by the end of this century (IPCC, 2007a; Jones et al., 2009).

The industrially developed signatory countries of the Kyoto Protocol accepted the reduction of GHG emissions of $80 \%$ until 2050, while the final goal is a $\mathrm{CO}_{2}$ neutral planet by the end of this century (IEA, 2012). The European Union set its own targets, announcing the reduction of GHG emissions by at least $20 \%$ compared to 1990 , while increasing the production and consumption of renewable energy by $20 \%$ until 2020. However, due to contextual limitations of member countries (e.g. the level of industrial development and climate characteristics of each region) locally adjusted actions and instruments represent a necessity in reaching the anticipated general goals (IEA, 2010). The latest comprehensive report of the EEA (2015) underlines that there have been certain improvements regarding the environmental pressures in Europe. Dealing with the current environmental situation, trends and prospects across all 39 member countries and cooperating countries of the EEA (including 
Serbia), the collected data indicate that since 1990 the GHG emissions have decreased by $19 \%$, despite a $45 \%$ increase in economic output (EEA, 2015). Furthermore, the use of fossil fuels and the emissions of some pollutants from transport and industry have been reduced, waste production has declined, while recycling rates in most countries have improved (EEA, 2015). Unfortunately, in spite of these positive trends, the emissions of GHG on a global level increased by $45 \%$ since 1990 and by $30 \%$ since 2000 , while in 2010 an increase of 5.8\% was detected (Olivier at al., 2011).

\section{Research Flows and Policy Responses}

Considering the global scale of climate change and its anticipated consequences, it is not surprising that the body of studies and documents focused on this problem is expanding. In general, there are several streams of research targeting climate hazards and vulnerability (McEntire, 2005), climate mitigation (Condon et al., 2009; IPCC 2007c; Prasad et al., 2009), climate adaptation (Condon et al., 2009; Hunt and Watkiss, 2011; Satterthwaite et al., 2009) and problems of social and economic transition (Brown, 2011; Hamilton, 2010). Additionally, the problems related to the public communication of climate change moulded by capitalism, modernity and science are also studied (Malone, 2009), as well as a limited perception and a low level of environmental awareness (Moser, 2010). Meanwhile, three main categories of policy responses could be identified - political (oriented toward problems of governance, synchronisation of policy responses, poverty reduction), sectoral (especially targeting sectors of energy, transportation and construction) and spatial - from the level of regional urban formations, to the problems of urban form and urban systems (Balaban, 2012).

Until 2010 and the adoption of the Cancun Adaptation Framework the issues of climate mitigation were dominant in scientific literature, institutional documents and practice. However, this document, created under the UN Framework Convention on Climate Change, addressed the equal importance of climate adaptation which should be developed and implemented via national plans and strategies. Adaptation to climate change, defined as the ability of the environment to support change without creating hazardous situations (Giddens, 2009) while moderating harm or exploiting beneficial opportunities (IPCC, 2001), has mostly been tackled on the level of preparatory activities and increased awareness, lacking actual effects on the environment (European Commission, 2013a; 2013b). Considering the diversity of regions across Europe, which reflects on possible impacts and adaptation capacity (IPCC, 2014a), the European Union has accepted the EU Strategy on adaptation to climate change (European Commission, 2013a) which was followed by 21 national adaptation strategies and 12 national action plans adopted in 2014 (EEA, 2014). Although the adaptation capacity of Europe is described as high compared to other regions in the world, the Strategy supports several complementing aspects of adaptability - from its integration with already existing sectoral policies and funding, to research and knowledge exchange (EEA, 2015).

\section{Cities As Nodes of Climate Adaptation}

Having in mind that a major share of population growth during the next decades will originate from urban areas (United Nations Department of Economic and Social Affairs, 2008), the importance of cities is underlined in various documents, reports and strategies related to climate adaptation. 
The unparalleled pace and intensity of urbanisation process is also visible in discouraging data describing urban areas as major consumers of produced energy (two thirds of the total energy use), estimating that this trend will reach $73 \%$ by 2030 (IEA, 2008). However, cities, as nodes of global and regional networks, could play several roles in the process of addressing climate change. They could be seen as contributors to GHG emissions, but also as very sensitive and vulnerable receptors exposed to climate change risks. Furthermore, cities, as generators of trends and innovations, certainly provide a vivid diffusion and exchange of information and knowledge which could be used for social, technological and environmental improvement. Nowadays, this ability of the urban environment is especially important in the domain of GHG reduction, which could be achieved through structural modifications and behavioural changes (Satterthwaite et al., 2009; Uhel and Georgi, 2009). Therefore, a growing research area interlinking cities and climate change targets at various scales and spheres of interest (While and Whitehead, 2013), as well as the emerging mitigation and adaptation initiatives in urban communities (Castán Broto and Bulkeley, 2012).

Obviously, cites are challenged by numerous external and internal threats and contradictions which have to be addressed in order to provide the anticipated carbon-free and climate friendly development. The current research, policies and practice on different levels have instigated a number of positive changes (UN Habitat, 2009) but their outcome is frequently perceived as vague or debatable (Betsill and Bulkeley, 2007).

\section{CLIMATE CHANGE VS. LOCAL FEEDBACK}

The territory of Serbia, as a part of the region of Central and Eastern Europe, represents an area vulnerable to climate change. The main observed and projected impacts from climate change include increase in warm temperature extremes, decrease in summer precipitation, higher water temperature, increasing risk of forest fires and decrease in economic value of forests (IPCC, 2007a; EEA, 2012). However, the effects of global warming are already evident and the weather data collected by the Belgrade Meteorological Observatory in the period 1888-2008 confirm a temperature increase during the 20th century, especially after 1990, while year 2000 is marked as the warmest one (Karadžić and Mijović, 2007). Having in mind that the estimated temperature growth for this part of Europe is between $2.2^{\circ} \mathrm{C}$ and $5.1^{\circ} \mathrm{C}$ by the end of the century, a number of negative trends caused by climate change are expected to influence local biodiversity, production of food and energy, water supplies, as well as the domain of economy, human health and general well-being (EEA 2015; IPCC, 2007; UNECE, 2007).

\section{The Condition of the Environment}

The level of GHG emissions in Serbia can only be perceived through estimations of IEA (International Energy Agency), IPCC, UNEP (United Nations Environment Programme) and World Bank. According to the sources, Serbia is responsible for $0.17 \%$ of global GHG emissions, which positions the country on the 80th place among global GHG emitters and the 58 th place among global $\mathrm{CO}_{2}$ emitters (IEA, 2009). On the European level, Serbia is ranked much higher, especially regarding a correlation between GHG emissions and Gross National Income. Consequently, the estimated amount of 6.2 tons $\mathrm{CO}_{2}$ / per capita is double than the average in the same 
income group, while on the global level this number is five times higher. Therefore, considering the size of its territory, population and economy, Serbia has an evident impact on climate change (IEA, 2011).

According to the Initial National Communication of the Republic of Serbia - INCRS (2010), which was the first national report on climate change, the largest share of GHG emissions in 1990 originated from energy sector $(77.69 \%)$, followed by agricultural production $(14.64 \%)$, industry $(5.28 \%)$ and communal landfills and sludge waste $(2.39 \%)$. The situation was similar in 1998 with slightly changed numbers: energy sector declined to $76.19 \%$, agriculture to $14.32 \%$, as well as the impact of communal landfills and sludge waste $(4.04 \%)$, while the share of industry in total GHG emissions increased by only $5.46 \%$. The emissions from fossil fuel combustion in the energy sector represented $94.1 \%$ of the total $\mathrm{CO}_{2}$ emissions in 1990 (comparing to $93.73 \%$ in 1998) and the remaining share (5.89\%) came from industrial processes (comparing to $6.27 \%$ in 1998). The same document also describes climate change scenarios based on regional climate model integrations. According to the baseline scenario (A1B), covering periods 2001-2030 and 2071-2100, the estimated temperature increase is 0.8 to $1.1^{\circ} \mathrm{C}(2001-2030)$ and 2.4 to $2.8^{\circ} \mathrm{C}(2071-2100)$. The anticipated increase of GHG emissions is $112.23 \%$ in 2012 and $120.41 \%$ in 2015 , comparing to the data from 1990. The second scenario (A2) includes mitigation effects focusing only on the period 2071-2100. It foresees an increase from 3.4 to $3.8^{\circ} \mathrm{C}$, and an increase of total GHG emissions of $110.56 \%$ in 2012 and $111.66 \%$ in 2015.

The data presented in the INCRS, as well as in other reports, analyses and estimations, are a good indicator of the specific socio-economic and political background of the country. The data related to the consumption of energy from 1990 to 2000 (EEA, 2011) reveal a decreased share of industry (51\% to $31.1 \%$ ) and an increased share of consumption from households and services (42\% to 58\%). Furthermore, during the last decades Serbia has been dealing with the problems of uncontrolled urban growth, depopulation of rural areas and illegal sprawl of built environment. The situation was especially difficult during the 1990s, when the economic crisis influenced a low level of employment, decrease of production, transport and available housing capacities, a lack of adequate infrastructure and waste management. Simultaneously, some important planning documents and laws were disregarded and the scale of illegally built areas drastically increased causing negative effects on the environment. Consequently, the increase of GHG emissions has been detected, as well as reduced energy efficiency, ineffective protection/preservation of natural and energy resources and undeveloped environmental consciousness (Đukic and Stupar, 2011).

\section{Following Global Framework(s), Establishing Local Regulation}

On its way toward climate adaptation and mitigation, Serbia, as a part of the international community, has ratified all major agreements and conventions on global warming, including the Vienna Convention (1988), the Montreal Protocol (1990), UN Framework Convention on Climate Change (1992), four amendments to the Montreal Protocol (2004), the Kyoto Protocol (2007) and the Aarhus Convention (2009). They all outline a general framework providing important principles, guidelines, recommendations and instruments which could slow down the pace of global warming simultaneously imposing new environmental and energy requirements to signatory countries. It is important to notice that Serbia 
did not have an obligation to reduce GHG emissions between 2008 and 2012, but it was required to prepare national and periodical reports for the United Nations Framework Convention on Climate Change (UNFCCC). Additionally, there was a number of tasks oriented to international cooperation in the field of climate research and systematic observations, transfer of knowledge and clean technologies, as well as the introduction of measures related to mitigation, education, training and public communication of climate change. However, the majority of activities, which followed the ratification of international documents, were focused on establishing a new legal framework, lacking the expected elaboration in projects and initiatives.

The first important step was the adoption of four environmental laws in 2004 - the Law on Environmental Protection (Zakon o zaštiti životne sredine), Law on Strategic Assessment of Environmental Impacts (Zakon o strateškoj proceni uticaja na životnu sredinu), the Law on Environmental Impact Assessment (Zakon o proceni uticaja na životnu sredinu) and the Law on Integrated Prevention and Pollution Control (Zakon o integrisanom sprečavanju $i$ kontroli zagađivanja životne sredine). The next step of synchronization with the EU represented the adoption of a set of laws in the field of environmental protection (2009) and the National Program for Environmental Protection approved in 2010. In 2007, the Belgrade initiative for the enhancement of sub-regional cooperation in SE Europe was adopted to enable regional networking and cooperation in the domain of climate change, as well as to provide a training/education of national negotiators participating in processes and projects under the UNFCCC. The focus of this initiative was on issues of vulnerability, adaptation and knowledge - its exchange, dissemination and integration into future actions. Another regional initiative was proposed during the same year, as a result of the Sixth Ministerial Conference of UNECE Environment for Europe held in Belgrade. The outcome was the establishment of the Sub-regional SE European Virtual Climate Change Centre in 2008. All these steps were necessary in order to provide a reliable GHG inventory, synchronize national and EU legislation and to initiate work on strategic documents and action plans dealing with climate change and possibilities of social and economic adaptation to its consequences (Slunge et al., 2008). Consequently, Serbia got another important document the National Strategy for Sustainable Development NSSD (Nacionalna strategija održivog razvoja, 2008), which defines a set of goals focused on harmonization of national regulations with the EU conventions and international agreements; institutional aspect of implementation of climate protection policies; climate adaptation and its reflections on economic and healthcare system.

As part of the UNFCC requirements, the INCRS was prepared in 2010, providing necessary information about the general national circumstances and presenting data related to GHG emissions in the period 19901998. The document incorporates sections dedicated to vulnerability assessment, climate change impacts and proposed adaptation measures defined in accordance with two possible scenarios of climate change (already mentioned in the previous chapter). The document also provides mitigation assessment until 2015, focused on sectors of energy, industry, agriculture, forestry and waste management. Underlining the importance of research activities and systematic observations, as well as a necessity of education, training and public awareness of global warming and GHG emissions, the INCRS considers the detected state of implementation of 
the UNFCC, defining the needs in a domain of finances, technology and capacity building (Initial National Communication of the Republic of Serbia, 2010). The following report is scheduled for 2016 and it should include additional analyses of hydrological conditions and water resources, agriculture and forestry, with proposed adaptation measures.

In November 2014, the government of the Republic of Serbia officially proclaimed a resolution on establishing the National Council for Climate Change, which will cover monitoring, development and implementation of national and sectoral policies and other planning documents related to climate change. The activities of the Council are also directed toward improvement and coordination of policies and actions in accordance with international obligations of Serbia, synchronisation and upgrading of the legislative framework and promotion of issues related to problems of global warming. Simultaneously, the Ministry of Agriculture and Environmental Protection announced that the first National Action Plan of Adaptation to Changed Climate Condition should be completed by the end of 2015 and is supposed to include a thorough financial analysis of implementation of adaptation measures (Zelena Srbija, 2014). The Ministry has already initiated work on legislation related to monitoring and reporting about GHG effects and other problems caused by global warming and the implementation of a new legal framework should start in 2018, after completion of a new Strategy and Action plan.

\section{The Urban Challenge}

Considering the impact of urban areas on climate change, Serbia produced several documents in order to regulate and control environmental problems on various spatial levels. These documents mostly target the issues of pollution, energy efficiency and negative effects of climate shifts. The Spatial Plan of the Republic of Serbia (1996) represents the main document for strategic spatial development. It is used as an outline for synchronization and integration of different strategies and plans covering different aspects of spatial development. However, the importance of environmental aspect was additionally emphasised by the Law on Strategic Assessment of Environmental Impacts (2004) providing a legal framework for obligatory environmental evaluation of regional and urban plans. The Law on Planning and Construction (Zakon o planiranju i izgradnji, 2009) is directly focused on problems of built environment, relating the design, use and maintenance of new buildings with the approved (and certified) energy characteristics.

The NSSD of 2008 also recognizes problems related to urban environment, especially in the sectors of housing, industry and transport. Its priorities are, therefore, focused on the introduction and intensified use of clean technologies and renewable energy, as well as increased energy efficiency. The Law on the Spatial Plan of the Republic of Serbia from 2010 to 2020 (Zakon o prostornom planu Republike Srbije od 2010 do 2020, 2010) is even more specific, targeting a number of environmental challenges in cities from uncontrolled expansion of built up areas and insufficient recycling of building land, to reduced energy efficiency and increased GHG emissions. Consequently, it underlines a necessity to protect and preserve natural resources, to rationalise their use under energy transition and to reactivate environmental/ecological consciousness. Stressing the importance of higher energy efficiency as an important environmental and economic goal on national level, the document includes a set of objectives related 
to the current state of energy consumption, future legal framework and synchronization of standards between the Serbian and the EU.

The challenges generated by climate change have been recognized by the Serbian government and included in the legislation framework on all spatial levels. However, following the international agreements, global trends and the EU demands is not an easy task, especially in a sensitive local context which has been facing numerous social, economic and environmental problems for more than two decades. Nevertheless, some of the innovations detected by UN Habitat (2009) - e.g. the introduction of green infrastructure and the upgrading of eco-efficiency - could now be recognized in Serbian cities. Meanwhile, the issues of renewable energy, sustainable transport or mobility management in urban areas remain embedded in planning documents or tackled by legislation, but their implementation is still on hold.

\section{TOWARD CLIMATE ADAPTATION: CHANNELS OF EXCHANGE AND INTERACTION}

Although reformed legislation represents a necessary foundation for achieving internationally acknowledged environmental aims, its active application in Serbia remains inefficient due to several reasons - a low level of environmental/climate change awareness, outdated institutional system, undeveloped procedures and the lack of funds for implementing measures presented in documents on spatial development, energy efficiency and environmental quality (Lazarević-Bajec, 2011). Consequently, it is necessary to define economically and socially sustainable methods/ approaches to climate adaptation which will take into consideration all current drawbacks, providing a high level of accessibility for different groups of users, fast and efficient application on all spatial levels and lower costs of use/implementation. Considering that one of the strategic aims of the Republic of Serbia is directed toward development of a knowledgebased society (Nacionalna strategija održivog razvoja, 2008), the importance of knowledge/information exchange and its application in a process of climate adaptation should be additionally emphasised and elaborated on the local level, in order to overcome limitations imposed by the obduracy of urban socio-technical change (Hommels, 2005).

\section{Global Trends}

On a global level, information networks represent one of main features of contemporary urban life whose complexity and efficiency have a significant impact on urban functionality (Castells, 2009; Coward and Salingaros, 2004). They successfully connect environment and people by supporting an efficient exchange through learning and understanding of environmental processes and urban systems, continuously evaluating possible outcomes and responding to detected anomalies. At the same time, advanced technologies have provided a simultaneous existence of a material and digital realm tracing a path for new modes of communication and interaction which redefine already existing urban patterns (Aurigi and De Cindio, 2008; Castells, 2004; Drewe, 2000; Fusero, 2009; Graham and Marvin, 1996).

The digital form of information networks enables better (and instant) detection of changes, increases the speed of data transmission and their analyses thus providing a better insight into urban processes, multiplying challenges and potential solutions. Focusing on the problem of climate 
shift, the synergy of information networks and modern technologies directly influence the ability of cities to be resource-efficient and oriented toward the reduction of GHG emissions, while open information flows play a significant role in minimising carbon footprint. However, information flows have to be transparent (Booher and Innes, 2002) and the collected/transmitted data has to be easily interpreted and understood in order to enhance their usability in various processes oriented toward climate adaptation and mitigation (Lemos et al., 2012). Therefore, it is not surprising that many cities already use readily-available technologies and real-time systems for information transparency, monitoring and decisionmaking, targeting environmental issues within different sectors and spatial scales.

The information networks represent a powerful tool for communicating climate change. For example, they facilitate interaction between all levels of governance and stakeholders improving awareness (Kousky and Schneider, 2003) or identifying potential climate risks and adaptation priorities (Bulkeley, 2010). Furthermore, they could be used for management of complex ecosystems (Bodin and Crona, 2009) and implementation of collaborative planning (Healey, 2006). Their role is also visible in the domain of formal and informal social networks, especially on a local level which is considered as optimal for creating and implementing adaptation strategies (Kern and Alber, 2008) and developing adaptive capacity (Pelling and High, 2005). Supported by new technologies, information flows connect social, technological and natural systems by different media, targeting sectors of services, mobility and government on our way toward smarter cities with low carbon economy.

Nowadays, there are three main types of networks applicability, dealing with main challenges of the anticipated climate-friendly development of urban(izing) areas - human behaviour, ecological awareness and general efficiency. The first type is focused on modifications of our behaviour, in accordance with the evolving understanding of environmental problems. The main role of this type of information networks is dissemination of information and knowledge related to the problems of climate shift and, depending on local context and the anticipated scale and timing of impact, it could be conducted in situ and/or through digital networks. If conceived as diffusion in real space and time, the exchange of information usually represents a part of education programs and projects, with an already defined thematic framework, time-line and audience/participants. Meanwhile, digital networks provide a continuously expanding and globally visible resource of information/knowledge which could be accessed via gateways (web-site-s, blogs and social networks) by unknown users. Although this mode of diffusion could have a certain level of interactivity, its influence on our behaviour is mostly passive, dispersed and delayed.

The use of information networks for developing our ecological awareness is primarily based on digital systems which detect and collect environmental data and make them broadly visible. The link between environment and users could be established through personal and public interfaces providing easy access to information related to places, processes and activities which could be used for moderation of our life-styles and consumption patterns, management of resources and urban systems, or as a notification/alarm related to social, ecological or health issues. This type 
of information networks can also include real-time interaction with users enabling their active participation in detecting urban problems.

The third mode of applicability of information networks is focused on the problem of efficiency and in this case both physical and digital networks have their important role in knowledge transfer and implementation of anticipated programs. Considering the negative impact of numerous carbon-intensive activities (especially sectors of transport, energy, infrastructure, agriculture) these networks could be oriented toward individuals, specific groups or municipal, regional and transnational systems, aiming to rationalise and minimise use of available time and resources. Consequently, they facilitate or complement management, directly or indirectly contributing to the reduction of GHG emission.

The overlapping of material and digital information networks could redefine our response to climate change simultaneously improving urban performances within eco-oriented economic development. Efficiently detecting, collecting, analyzing and processing different kinds of data certainly improves our knowledge and facilitates decision-making, but comprehensive actions in real space and time cannot be replaced by digital counterparts, especially in areas without sufficient technological support.

\section{Local Adjustment}

The use of information networks in climate change adaptation in Serbia follows a globally accepted application pattern, mainly focusing on public communication of climate change. However, their use in organisation and performance of urban systems still has to develop. Considering the importance of knowledge/information dissemination in climate adaptation (Castán Broto and Bulkeley, 2012; Hunt and Watkiss, 2011) it is possible to distinguish two basic levels of application of information networks institutional (governmental) and non-institutional (non-governmental). In both cases, activities conducted via information networks target consequences of carbon-intensive human behaviour, lack of ecological awareness and questionable general efficiency, simultaneously dealing with a number of local limitations. On the institutional level, use of information networks is either related to communication with the public (introduction of new environmental laws, international initiatives, and projects) or represents part of an international agreement (e.g. establishment of on-line data bases and registers). It is funded by the government (national, regional or local level) and/or from international funds accessible via different projects of cooperation. Meanwhile, the noninstitutional level, mostly dealing with various environmentally focused initiatives, is directly enabled, conducted and/or reinforced by information exchange and financially supported by international, regional or local funds.

Currently $62.8 \%$ of households in Serbia have internet access $(67.8 \%$ in urban and $51.1 \%$ in rural areas), while the share of internet users, according to their employment status, reveals that all students, $84.3 \%$ of employed, $58.9 \%$ of unemployed and $29.7 \%$ of other categories use internet (Upotreba informaciono-komunikacionih tehnologija u Republici Srbiji, 2014). Therefore, communication, transmission and exchange of information have to use both physical and digital channels of communication in order to reach all categories of users and provide a flexible, efficient and comprehensive coverage of climate problems. This duality is especially important for programs, activities and initiatives directed to improvement 
of environmental consciousness which should further reflect on climate adaptation of life habits.

\section{Institutional (Governmental) Level}

One of the main governmental sources on environmental issues is the Serbian Environmental Protection Agency (SEPA), established within the Ministry for Agriculture and Environmental Protection of the Republic of Serbia. Its activities are focused on development and management of national information system for environmental protection; collecting and processing of data; reporting on environmental conditions; monitoring of environmental quality and implementation of adopted programs; directing the National laboratory; cooperation with the EEA and the European Environment Information and Observation Network (EIONET). Consequently, their web-site provides information related to their services, environmental condition, different thematic areas, important documents, publications and news (events, projects, public communications), as well as links to other environmental projects launched by the government (SEPA, 2013). This web-site also hosts the Ecoregister - the National Metaregister for Environmental Information and the National Register of Pollution Sources, a result of the implementation process of the Strategy for the Implementation of the Aarhus Convention (i.e. The Convention on Access to Information, Public Participation in Decision-making and Access to Justice in Environmental Matters, 2009).

The Ecoregister represents a portal to existing databases and documents with environmental information, which provides quick, easy and simple access for the public. It is a result of the project conducted by the Ministry of Energy, Development and Environmental Protection of the Republic of Serbia and the SEPA, with the support of the OSCE - Organization for Security and Co-operation in Europe (Ekoregistar, 2012). The content is continuously updated, allowing a certain level of interactivity between users and editors that could be established by proposing the inclusion of a new document or an institution via digital submission form. Unlike the Ecoregister, which acts as a comprehensive data base with flexible content and structure, the establishment of the National Register of Pollution Sources was a real challenge considering the previous condition of information records, which were fragmented, incomplete and incompatible with the required format. Following the Protocol on Pollutant Release and Transfer Register (as an integral part of the Aarhus Convention), a unique form for submitting data was created, enabling an efficient and synchronized collecting of information on sources and of the extent of environmental pollution. The main aim is inclusion of this register into a geo-spatial information service established under the EU directive INSPIRE (Infrastructure for Spatial Information in the European Community). Currently, the National Register does not provide data on air and water emission, while the last entry for other sections (including pollutant release and transfer, waste, and BREF - Best Available Technology Reference Documents) was made in 2013.

It is interesting to mention that the information on pollutant release and transfer were recently used for another approach to raising environmental awareness merging institutional and non-institutional levels. The webservice Paastot.fi (2014) is based on data of emissions originating from industry, gathered in the European Pollutant Release and Transfer Register (E-PRTR). It includes all EU countries, Iceland, Norway, Switzerland and Serbia, providing the interactive map interface with the biggest polluters 
around Europe, according to the type of emission and its impact on the environment. The service was awarded with the Grand Prix of the 2014 Apps4Finland competition for open data, due to its easily understandable format of presenting and comparing complex information by changing the spatial and time scale.

The institutional information networks also deal with the problem of efficient use of resources and this kind of service either utilizes already available data bases, or is more advanced, allowing visualization/mapping of collected data, as well as their monitoring, analysis, reporting, evaluation and management. The first type indirectly supports management of environmentally damaging urban systems by providing up-to-date information about traffic congestion on municipality web-sites (e.g. the data base of the Secretariat for traffic of Belgrade). However, it should be technologically upgraded with an active exchange between providers and users of information in order to directly facilitate more efficient use of transportation systems by enabling multimodality, monitoring the condition and improving the visibility of real-time information on choices, availability and surrounding urban activities.

The other type is usually based on GIS technology and created for specialized institutions. Some interesting examples are the Belgrade biotope GIS, primarily used by the Secretariat for the Environment of Belgrade, but partly available to other interested users though special portal (htps://gisbiotopa.beograd.gov.rs), or the GIS of Belgrade green areas, which is currently under construction for the Pubic company 'Belgrade Greenery' (Mapsoft, 2015).

In general, information exchange provided by formal (governmental) bodies in Serbia is conditioned by the level of governance, its activities and development strategies. However, the communication on environmental issues, climate change and climate adaptation has been conceived as a public display of important documents and institutions, environmental data, national and international activities/projects and successful examples, but mostly without elaborated (interactive) interface. Although collecting and processing of data is mostly conducted in digital format, transmission could be diverse - via digital networks, printed material, public presentations, events etc. New modes of communication do allow better visibility and easy access but they are mostly used by other institutions or professionals related to the topic because data format is not adjusted to the general public. Therefore, even their role of passive inductors of behavioural changes is questionable and limited, although some exceptions could be found on the local level of governance. A good initiative (although temporary) was the so-called Eko-portal of the Belgrade municipality Stari Grad, established in 2010 which provided a virtual meeting place for all citizens and representatives of local government interested in protection and improvement of environment quality (Eko portal opštine Stari grad, 2010). Similar models could be found in other municipalities in Serbia, usually as part of simple web-platforms for interaction between citizens and local governance, covering general urban problems. Meanwhile, environmental issues are communicated via different workshops and events, which are supported by local governments (and announced on their web-sites) but usually organized by non-governmental organisations and groups. Considering current condition, it is evident that the services of institutional information networks should be extended on all levels, opening new user-friendly channels, frequently updating their content and 
providing visually interactive interpretation of data which would allow better understanding of environmental problems.

\section{Non-Institutional (Non-Governmental) Level}

Information flows initiated by non-governmental organizations and groups in Serbia provide both passive and active perception of environmental issues, relying either on a specific thematic focus or providing their interlinking. The passive reception of information is enabled via web-sites, mass-media, social media or printed material on environmental trends, displaying different aspects of sustainability and resilience. The simplest mode of this transmission could be found in digital editions of magazines (e.g. Ekologija magazin, 2009-2014; Popular Science, 2015) or thematic portals, such as Zelena Srbija (Green Serbia), a project launched in 2009 by the press agency Beta. Supported by the Ministry of Natural Resources, Mining and Spatial Planning of Serbia, the Institute for Sustainable Communities and the Embassy of the USA, it aims at environmental protection and promotion of healthy life-styles (Zelena Srbija, 2009). The project, titled as Adapt Yourself (Adaptiraj se, 2015), backed by Klimatski forum (Climate forum), South East European Forum on Climate Change Adaptation, Austrian Red Cross, Centar za unapređenje životne sredine (Environment Improvement Centre) and WWF (World Wide Fund), also provides an open and comprehensive knowledge-base but with a single thematic focus - climate change adaptation and different aspects of this problem.

A more advanced and (inter)active mode is applied by several NGOs using both digital and physical information networks to tackle environmental, educational and cultural aspects of behavioural changes and energy transition. Consequently, they improve communication on climate change adaptation and actively involve citizens in various activities supported by international, national and local institutions and funds. Although their digital content is open to everyone, the public scale which they activate and mobilize depends on their territorial focus (from municipality to regional and national level), while their international visibility is conditioned by their membership in global organizations, international character of their activities and English translation of web-content. For example, the environmental movement Supernatural is one of the most globally integrated Serbian NGOs, being a member of United Nations Global Compact and Slow food, as well as a partner of WWF, Friends of the Earth, DC Environmental Network, Europarc federation, Ministry of Environment of the Republic of Serbia, City of Belgrade and other renowned institutions (Supernatural, 2015). The interdisciplinary team of professionals and activists is in charge of a set of programs including Supernatural festival, a national frequency radio program (Supernatural FM), Supernatural Film production, Green community, Green Biz and Think Tank. Their initiatives are also related to education, eco tourism, art and architecture. However, the activities of the Supernatural are oriented mainly to urban audience and spaces, while the Green Network of Vojvodina, as an internationally recognized NGO covering activities in the Autonomous Province of Vojvodina, uses similar concept of dissemination additionally extending it to agriculture and rural development (Zelena mreža Vojvodine, 2015). On a local level, the example of good practice represents the association of citizens Stakleno zvono (Glass bell) from the city of Kragujevac. Their internet portal and the e-magazine Stakleno zvono were created as an upgrading of a television program under the 
same name, regularly broadcasted since 2000 (Stakleno zvono, 2015). They also organize numerous events, conduct projects and studies, collect and analyse scientific/professional news and publish on environmental problems, acting as a successful model of knowledge dissemination which could be implemented by similar organizations.

The third mode of the application of non-governmental digital networks in Serbia is used for specific web-services, resulting from changes of life-style or aiming at the efficiency of transport. The internet project BUDIEKOFINa. COM (2010), launched by the private Agency for marketing and consulting Total Idea, tends to increase ecological awareness of users, establish Serbia as a brand name of eco-tourism and provide a system which enables on-line shopping of eco-products from a single access point. Under the motto "Be good, be green, be eco-nice" it promotes authenticity of local eco-production and stimulates networking between institutions, NGO-s and producers. The web-site is supported by several national and regional governmental institutions, media, education networks and other ecospecialized organizations and services. The other example is related to a trend of carpooling/rideshare, which potentially rationalizes transport costs, lowers fuel usage, decreases traffic congestion and, consequently, reduces GHG emission. The web-site Timskavoznja.com, focused mostly on countries of ex-Yugoslavia, enables this kind of service leading toward climate change adaptation. However, this kind of service could be further upgraded by introducing real-time sharing (also known as dynamic, instant or ad-hoc sharing), which combines GPS navigation devices, smart phones and social networks via special network service and provides higher environmental benefits (Levofsky and Greenberg, 2001).

The rise of social media has also created a new space for more interactive exchange of knowledge and networking which could be illustrated by several communities launched on Facebook - for example, Cikliranje aiming at sustainable urban mobility, EKOpokretači - promoting recycling, Gerila baštovani - community focused on urban gardening. However, all these initiatives are not sufficiently developed or recognized among potential users and their impact on environment is still undetectable.

The review of available information flows in Serbia demonstrates that the information networks set up by NGOs, private companies or informal groups provide a more flexible, creative and multi-optional framework for exchange and diffusion of knowledge on environmental issues and climate adaptation. However, their digital interfaces could be additionally improved and continuously upgraded by new contents, links and applications in order to increase their visibility, accessibility and, consequently, impact on society and space. Considering that the number of users accessing internet via mobile phones has increased from $46.1 \%$ in 2013 to 61\% in 2014 (Upotreba informacionio-komunikacionih tehnologija u Republici Srbiji, 2014), a further adjustment to Android and iOS platforms is recommendable. At the same time, a trend of vis-à-vis communication and active involvement in public events should be further stimulated, allowing individual expression and tangible results.

\section{CONCLUSION}

The process of climate change adaptation in Serbia has been gradually introduced to national legislation and society, although its major problem represents insufficient or inadequate implementation due to a low level 
of environmental awareness, outdated procedures and instruments, as well as a complex socio-economic situation in the country. However, information networks have been recognized as an important element of conducted activities enabling efficient transmission and dissemination of environmental knowledge, data and up-to-date trends and ideas, especially in the urban context. Through a real-time diffusion (face-toface communication during events, meetings and workshops) and digital accessibility (via web-sites, social medias) they provide an insight into local and global environmental challenges, present possible/successful solutions and mobilize different categories of participants to be included into online or in-situ activities. Although information flows improve general understanding of climate problems and redefine eco-perception, their application in the domain of efficiency of urban performances (including transport, production, consumption and waste) or disaster situations is still undeveloped. Therefore, the use of digital systems in detecting environmental data (via sensors), making them immediately available (via networks) and efficiently responding should be additionally stimulated.

The application of information networks in climate change adaptation of Serbia should also allow both vertical and horizontal communication. While vertical flows are dominant in most reviewed examples, the benefits of horizontal interchange include immediacy and accuracy of information within groups of users, flexibility of content, openness of data-bases and the process itself, as well as the highest possible level of accessibility, adjusted to various social needs and the technological competence of users. Furthermore, currently used digital networks should increase level of interactivity, by using all the benefits of the emerging Web 2.0 concept which allows direct involvement of users in creating and modifying the open source software via mashup, a web application able to merge data from different sources, including environmental or participatory sensing conducted via personal gadgets and social media. Therefore, the application of Web 2.0 and mashup could be an additional element in climate change adaptation, especially in the case of Serbia, which faces a high level of contextual uncertainty and a low level of environmental control. Apart from this solution, which can provide a simple, affordable and user-friendly platform, information networks should gradually include globally emerging trends of Open Network Environment, Internet of Things (IoT), Cloud Computing, Open Data and Big Data concepts which provide overlapping and interlinking of the physical and digital environment, stimulating adjustment of our perception, actions and decisions toward climate change adaptation.

The Clean revolution promoted by the SMART 2020 report by The Climate Group (2008) suggests several development imperatives enabled by ICT "standardize, monitor, account, rethink and transform", which should influence the reduction of GHG emissions and minimize the carbon footprint. All of them could be recognized to a certain extent in the case of Serbia, in the formal activities of the Serbian government and in informal and creative responses from the society. However, the current discrepancy between declarative statements and reality should be considered as a warning that climate change adaptation has to be visible beyond documents and web-sites, as a sustainable and interactive outcome of anticipated eco-oriented economic development and active community support. 


\section{ACKNOWLEDGEMENT}

The article is prepared as part of the research project titled "Studying climate change and its influence on the environment: impacts, adaptation and mitigation" (43007) financed by the Ministry of Education and Science of the Republic of Serbia within the framework of integrated and interdisciplinary research for the period 2011-2016.

\section{REFERENCES}

Aarhus Convention/Strategija za primenu konvencije o dostupnosti informacija, učešću javnosti u donošenju odluka i pravu na pravnu zaštitu u pitanjima životne sredine - Arhuska konvencija (2011) Službeni glasnik RS, br. 103/2011.

Adaptiraj se (2015) [http://adaptirajse.org/] Access Date (10.03.2015).

Apps4Finland 2013 competition (2014) [http://www.apps4finland.fi/ apps4finland-competition/] Access Date (10.03.2015).

AURIGI, A., De CINDIO, F., eds. (2008) Augmented Urban Spaces: Articulating the Physical and Electronic City, Ashgate, Aldershot, England.

BALABAN, O. (2012) Climate Change and Cities: A Review on the Impacts and Policy Responses, METU Journal of the Faculty of Architecture 29 (1) 21-44.

BETSILL, M., BULKELEY, H. (2007) Looking Back and Thinking Ahead: a Decade of Cities and Climate Change Research, Local Environment: The International Journal of Justice and Sustainability (12) 447-56.

BODIN, O., CRONA, B. I. (2009) The Role of Social Networks in Natural Resource Governance?, Global Environmental Change (19) 366-74.

BOOHER, D. E., INNES, J. E. (2002) Network Power in Collaborative Planning, Journal of Planning Education and Research 21(3) 221-36.

BUDIEKOFINa.COM (2010) [www.budiekofin.com; www.budiekofina. com; www.econice.rs] Access Date (10.03.2015).

BULKELEY, H. (2010) Cities and the Governing of Climate Change, Annual Review of Environment and Resources (35) 229-53.

CASTÁN BROTO, V., BULKELEY, H. (2013) A Survey of Urban Climate Change Experiments in 100 Cities, Global Environmental Change (23) 92-102.

CASTELLS, M. (2004) Space of Flows, Space of Places: Materials for a Theory of Urbanism in the Information Age, The Cybercities Reader, ed. S. Graham, Routledge, Taylor \& Francis Group, New York; 86-95.

CASTELLS, M. (2009) The Rise of the Network Society, Blackwell, Malden, MA.

CONDON, P. M., DUNCAN, C., MILLER, N. (2009) Urban Planning Tools for Climate Change Mitigation, Policy Focus Report Series, Lincoln Institute of Land Policy, Cambridge, USA.

COWARD, L., SALINGAROS, N. (2004) The Information Architecture of Cites, Journal of Information Sciences 30(2) 107-118. 
DREWE, P. (2000) ICT and Urban form. Urban Planning and Design - Off the Beaten Track, Design Studio "The Network City", Faculty of Architecture, Delft University of Technology.

ĐUKIC, A., STUPAR, A. (2011) Suočavanje sa klimatskim promenama: od evropskih strategija do lokalne realnosti/Facing the Climate Changes: From European Strategies to Local Reality, Arhitektura i Urbanizam (32) 35-48.

EEA (2010) The European Environment - State and Outlook 2010 (SOER 2010): Synthesis, European Environment Agency, Copenhagen.

EEA (2011) EEA Report 04/2011, Greenhouse Gas Emission Trends and Projections in Europe 2011, European Environment Agency, Luxembourg.

EEA (2012) Urban Adaptation to Climate Change in Europe, EEA Report No 2/2012, European Environment Agency, Copenhagen.

EEA (2014) National Adaptation Policy Processes Across European Countries - 2014, EEA Report No 4/2014, European Environment Agency, Copenhagen.

EEA (2015) The European Environment - State and Outlook 2015 (SOER 2015): Synthesis report, European Environment Agency, Copenhagen.

Eko portal opštine Stari grad (2010) [http://www.eko-portal.net] Access Date (10.03.2015)

Ekologija magazin (2009-2014) [http://www.ekologija.rs/] Access Date (10.03.2015).

EUROPEAN COMMISSION (2013a) An EU Strategy on Adaptation to Climate Change-Communication from the Commission to the European Parliament, the Council, the European Economic and Social Committee and the Committee of the Regions (COM (2013) 216 final), European Commission, Brussels.

EUROPEAN COMMISSION (2013b) Guidelines on Developing Adaptation Strategies (SWD (2013) 134 final), European Commission, Brussels.

FUSERO, P. (2009) E-City: Digital Networks and Cities of the Future, LIST Laboratorio, Barcelona.

GIDDENS, A. (2009) The Politics of Climate Change, Polity Press, Cambridge.

GRAHAM, S., MARVIN, S. (1996) Telecommunication and the City: Electronic Spaces, Urban Places, Routledge, London.

HAMILTON, C. (2010) Requiem for a Species: Why We Resist the Truth about Climate Change, Routledge, London.

HEALEY, P. (2006) Collaborative Planning: Shaping Places in Fragmented Societies (2nd ed.), Palgrave MacMillan, London.

HOMMELS, A. (2005) Studying Obduracy in the City: Toward a Productive Fusion between Technology Studies and Urban Studies, Science, Technology and Human Values 30(3) 323 -51.

HULME, M. (2008) The Conquering of Climate: Siscourses of Fear and Their Dissolution, Geographical Journal 174(1) 5-16.

HUNT, A., WATKISS, P. (2011) Climate Change Impacts and Adaptation in Cities: a Review of the Literature, Climatic Change (104) 13-49. 
IEA (2008) World Energy Outlook 2008, Geneva.

IEA (2012) CO2 Emissions from Fuel Combustion: Documentation for Beyond 2020 files (2012 edition) [http://wds.iea.org/wds/pdf/documentation_ co2_2012.pdf] Access Date (3.3.2015).

Initial National Communication of the Republic of Serbia under the United Nations Framework Convention on Climate Change (2010) The Ministry of Environment and Spatial Planning, Belgrade.

IPCC (2001) Climate Change 2001, Impacts, Adaptation and Vulnerability Contribution of Working Group II to the Third Assessment Report of the Intergovernmental Panel on Climate Change, Cambridge University Press, Cambridge.

IPCC (2007a) Climate Change 2007: Synthesis Report Contribution of Working Groups I, II and III to the Fourth Assessment Report of the Intergovernmental Panel on Climate Change, Cambridge University Press, Cambridge.

IPCC (2007c) Summary for Policymakers, Mitigation. Contribution of Working Group III to the Fourth Assessment Report of the Intergovernmental Panel on Climate Change, eds. B. Metz et al., Cambridge University Press, Cambridge, UK \& New York, NY, USA; 1-24.

IPCC (2012) Managing the Risks of Extreme Events and Disasters to Advance Climate Change Adaptation. A Special Report of Working Groups I and II of the Intergovernmental Panel on Climate Change, Cambridge University Press, Cambridge, UK/New York, USA.

IPCC (2014a) Climate Change 2014: Impacts, Adaptation and Vulnerability, Cambridge University Press, Cambridge, UK and New York, USA.

Istraživanje klimatskih promena i njihovog uticaja na životnu sredinu: praćenje uticaja, adaptacija i ublažavanje (2011/2015) [http://www. cleniam.rs/] Access Date (07.03.2015).

JONES, P., PINHO, P., PATTERSON, J., TWEED, C., eds. (2009) European Carbon Atlas: Low Carbon Urban Built Environment, Cardiff University, The Welsh School of Architecture, Cardiff. [http://www.lcube. eu.com/Euro_Carbon_Atlas/C23\%20European\%20Carbon\%20Atlas. pdf] Access Date (07.03.2015).

KARADŽIĆ, B., MIJOVIĆ, A., eds. (2007), Environment in Serbia: an Indicator-based Review, Belgrade, Serbian Environmental Protection Agency. [http://www.sepa.gov.rs/download/Environment_in_ Serbia_Full.pdf] Access Date (07.03.2015).

KERN, K., ALBER, G. (2008) Governing Climate Change in Cities: Modes of Urban Governance in Multi-level Systems, Proceedings of the OECD Conference on 'Competitive Cities and Climate Change', OECD, Paris; 171-196 [http://www.oecd.org/gov/regional-policy/50594939.pdf] Access Date (07.03.2015).

KOUSKY, C., SCHNEIDER, S. H. (2003) Global Climate Policy: Will Cities Lead the Way?, Climate Policy (3) 359-72.

LAZAREVIĆ-BAJEC, N. (2011) Integrating Climate Change Adaptation Policies in Spatial Development Planning in Serbia - a Challenging Task Ahead, Spatium (24) 1-8. 
LEVOFSKY, A., GREENBERG, A. (2001) Organized Dynamic Ride Sharing: The Potential Environmental Benefits and the Opportunity for Advancing the Concept, Transportation Research Board, 2001 Annual Meeting, Washington, DC.

LEMOS, M. C., KIRCHHOFF, C. J., RAMPRASAD, V. (2012) Narrowing the Climate Information Usability Gap, Nature Climate Change 2(11) 789-94.

MALONE, E. (2009) Debating Climate Change: Pathways through Argument to Agreement, Earthscan, Sterling, London.

MapSoft (2015) [http://www.mapsoft.rs/index.php/sr/gis-usluge/gisresenja/gis-zp] Access Date (10.03.2015).

McENTIRE, D. A. (2005) Why Vulnerability Matters: Exploring the Merit of an Inclusive Disaster Reduction Concept, Disaster Prevention and Management, 14(2) 206-222.

MOSER, S. (2010) Communicating Climate Change: History, Challenges, Process and Future Directions, WIREs Climate Change (1) 1- 8.

Nacionalna strategija održivog razvoja (2008) Službeni glasnik RS, br. 55/05, 71/05-ispravka i 101/07 .

OLIVIER, J. G. J., JANSSENS-MAENHOUT, G., PETERS, J. A. H. W., WILSON, J. (2011) Long-term Trend in Global CO2 Emissions. 2011 Report, PBL/JRC, The Hague.

Päästöt.fi (2015) [http://paastot.fi/] Access Date (10.03.2015).

PELLING, M., HIGH, C. (2005) Understanding Adaptation: What Can Social Capital Offer Assessments of Adaptive Capacity?, Global Environmental Change 15(4) 308-19.

Popular Science (2015) [http://popsci.rs/gradovi-klimatske-promene/] Access Date (10.03.2015).

PRASAD, N., RANGHIERI, F., SHAH, F., TROHANIS, Z., KESSLER,E., SINHA, R. (2009) Climate Resilient Cities: A Primer on Reducing Vulnerabilities to Disasters, World Bank, Washington DC. [http:// siteresources.worldbank.org/INTEAPREGTOPURBDEV/Resources/ Primer_e_book.pdf/] Accessed (10.03.2015).

Regionalni prostorni plan administrativnog područja grada Beogradaizmene i dopune (2011) Službeni list grada Beograda 38/11.

ROAF, S., CRICHTON, D., NICOL, F. (2005) Adapting Buildings and Cities for Climate Change: A 21st Century Survival Guide, Elsevier, New York.

SATTERTHWAITE, D., HUQ, S., REID, H., PELLING, M., ROMERO LANKAO, P. (2009) Adapting Cities to Climate Change in Urban Areas: the Possibilities and Constraints in Low and Middle Income Nations, Adapting Cities to Climate Change eds. J. Bicknell, et al., Earthscan, London; 3-34.

Secretariat for traffic of Belgrade (2015) [http://www.bgsaobracaj.rs/] Access Date (10.03.2015).

SEPA/Serbian Environmental Protection Agency (2013) [http://www.sepa. gov.rs/index.php] Access Date (10.03.2015). 
SLUNGE, D., EKBOM, A, DADLBERG, E. (2008), Serbia Environmental and Climate Impact Analysis, School of Economics and Commercial Law, Goteborg.

Stakleno zvono (2015) [http://staklenozvono.rs/] Access Date(10.03.2015).

Supernatural (2015) [http://www.supernatural.rs/] Access Date (10.03.2015).

THE CLIMATE GROUP on behalf of the Global eSustainability Initiative GeSI (2008) SMART 2020: Enabling the Low Carbon Economy in the Information Age. [http://www.theclimategroup.org/_assets/files/ Smart2020Report.pdf ] Access Date (07.03.2015).

Timska voznja (2013), [http://www.timskavoznja.com/] Access Date (10.03.2015).

UHEL, R., GEORGI, B. (2009) Key to a Low Carbon Society: Cities and Local Power, Low Carbon Cities - ISOCARP REVIEW 05, eds. C. Gossop, F. B. Alves, ISOCARP; 18-37.

UNECE (2007) Environmental Performance Review, Republic of Serbia-Second Review, United Nations, New York, Geneva; 9-12

UN-HABITAT (2009) UN-Habitat Climate Change Strategy 2010-2013, UNHabitat, Urban Environmental Planning Branch, Nairobi.

UN-HABITAT (2011) Global Report on Human Settlements 2011 - Cities and Climate Change, Earthscan, London.

UNITED NATIONS DEPARTMENT OF ECONOMIC AND SOCIAL AFFAIRS, POPULATION DIVISION (2008) World Population Prospects: The 2008 Revision, New York: United Nations [http://www. un.org/esa/population/publications/wpp2008/wpp2008_highlights. pdf] Access Date (07.03.2015).

Upotreba informaciono-komunikacionih tehnologija u Republici Srbiji, (2014) Republički zavod za statistiku Srbije, Beograd.

WHILE, A., WHITEHEAD, M. (2013) Cities, Urbanisation and Climate Change, Urban Studies 50(7) 1325-31.

WORLD BANK (2010) Cities and Climate: Change: An Urgent Agenda, World Bank, Washington.

Zakon o zaštiti životne sredine (2004) Službeni glasnik RS, br. 135/2004 i 36/2009.

Zakon o integrisanom sprečavanju i kontroli zagađivanja životne sredine (2004) Službeni glasnik RS, br. 135/2004 i 25/2015.

Zakon o planiranju i izgradnji (2009) Službeni glasnik RS, br. 72/2009.

Zakon o proceni uticaja na životnu sredinu (2004) Službeni glasnik RS, br. 135/2004 i 36/2009.

Zakon o Prostornom planu Republike Srbije (2010) Službeni glasnik RS, br.88/2010.

Zakon o strateškoj proceni uticaja na životnu sredinu (2004) Službeni glasnik RS, br. 135/2004 88/2010.

Zelena mreža Vojvodine (2002-2015) [http://www.zelenamreza.org/] Access Date (10.03.2015).

Zelena Srbija (2014) [www.zelenasrbija.rs] Access Date (10.03.2015). 
Alındı: 14.05.2014; Son Metin: 30.12.2015

Anahtar Sözcükler: Küresel 1sınma; iklim değişikliği uyumu; bilgi ağları; kent; çevresel gelişim.

\section{SIRBISTAN'DA İKLİM DEĞIŞiKIKLİĞİNE UYUM: BİLGİ AĞLARININ ROLÜ}

Küresel ısınma ve artan sera gazı emisyonlarının sebep olduğu problemlerin önemi, uluslararası toplum tarafından kabul edilmiş ve bu engelin aşılması için iklim değişikliği önlemi, azaltımı ve uyumuna yönelik çalışma, anlaşma ve politikaların sayısı artmıştır. Yeşil ekonomiye geçiş en üst seviyedeki kalkınma hedefi olarak belirlenirken, çevresel politikalar, ekonomik verimlilik, teknolojik gelişme ve davranışsal değişim arasında dengeli bir ilişkinin kurulması da cağımızın küresel görevlerinden birisidir. Bilgi ve yeniliklerin önemi üzerinde ayrıca durulurken; bunların kullanılabilirliği, yayılması ve değişimi, özellikle hassas yerel koşullar sebebiyle ciddi ekonomik, sosyal ve çevresel problemlerle yüzleşen toplumlarda, yeşil geçisin önemli desteklerindendir.

Bu makalenin de odağını oluşturan Sırbistan örneği, ülkenin yakın geçmişinde yaşadığı çalkantılı 20 yıla bağlı olarak, iklim değiş̧ikliği uyumu konusunda izlenebilecek olası yollardan birini sunmaktadır. 2000 yılından itibaren gerçekleşen demokratik değişimlerle birlikte çevresel problemler hem kurumsal (hükümete ait) düzeyde - yeni çevre kanunlarının çıkartılması, araştırma finansmanı, belirli dokuman ve stratejilerin hazırlanması ve uygulanması - hem de kurumsal olmayan (hükümet dışı) düzeyde - genellikle uluslararası, bölgesel ve yerel fonlar tarafından desteklenen çevre odaklı girişimlerde olduğu gibi - gözle görülür hale gelmiştir. Ancak her iki düzeyde de bilgi ağları, sürdürülebilir ve yerel iklim uyumu için gereken bir yaklaşıma imkan sağlayan, göz ardı edilemez yapısal bir bileşeni ifade etmektedir. Küresel eğilimleri takiben, Sırbistan'daki bilgi ağları temel olarak iklim değişikliğinin kamusal iletişimi konusunda, iklim uyumunun üç temel tematik alanını kapsayacak şekilde kullanılmıştır - insan davranışı, çevresel farkındalık ve genel verimlilik.

Tüm bu özgüllükleri göz önüne alarak, bu makale iklim değişikliğine hem küresel hem de yerel seviyede uyum konusunda bilgi ağlarının kullanıldığı belirlenen pratiklerin incelenmesini içermekte ve Sırbistan örneği kapsamındaki bazı fayda ve kısıtlamaları vurgulamaktadır. Makalenin ilk bölümünde iklim uyumu problemi konusunda küresel bir arka plan sunmakta, temel çevresel eğilimleri, araştırma problemlerini ve politika tepkilerini özetlemekte ve iklim değişikliği ile kent(leşen) çevre arasındaki ilişkiyi vurgulamaktadır. İkinci bölüm Sırbistan örneğine ayrılmış ve çevrenin genel durumu, yasal çerçeve ve kent bağlamının algılanması, tanınması ve bu bağlamın önceki gelişme dokümanlarına etkileri olmak üzere üç konu üzerinde durulmuştur. Üçüncü bölümde bilgi ağları, yapılı çevre/kentler ve iklim değişikliği arasındaki ilişki üzerinde durulmuştur. Bununla birlikte, küresel eğilimler ve Sırbistan örneği hakkında bir genel değerlendirme sunulurken, sonuç bölümünde belirlenen yerel zayıflıklar konusunda gerçekleştirilmesi mümkün olan iyileştirmelere yer verilmiştir.

\section{CLIMATE CHANGE ADAPTATION IN SERBIA: THE ROLE OF INFORMATION NETWORKS}

The importance of problems caused by global warming and increased GHG emissions have been recognised by the international community which responded to this challenge through a growing number of studies, agreements and policies dealing with climate change prevention, mitigation and adaptation. The shift to green economy is confirmed as 
the highest development aim, while establishing a balanced relationship between environmental policies, economic efficiency, technological upgrading and behavioural transition is one of main global assignments of our epoch. The importance of knowledge and innovations is also emphasised, while their availability, diffusion and exchange represent a key-reinforcement of green transition, especially in societies which are facing severe economic, social and environmental problems caused by sensitive local circumstances.

The case of Serbia, which is the focus of this article, presents one of possible paths towards climate change adaptation, conditioned by more than two turbulent decades of the recent history of the country. Since democratic changes in 2000, environmental issues have become visible on institutional (governmental) level - through introduction of new environmental laws, research funding, preparation and implementation of specific documents or strategies, and on non-institutional (non-governmental) level - as different environmentally focused initiatives, usually supported by international, regional or local funds. However, on both levels information networks represent an inevitable structural ingredient, which enables a sustainable and locally adjusted approach to climate adaptation. Following global trends, information networks in Serbia are mainly used in the domain of public communication of climate changes, covering three major thematic areas of climate adaptability - human behaviour, ecological awareness and general efficiency.

Considering all these specificities, the article provides a review of detected practices related to the use of information networks in climate change adaptation on both global and local level, stressing the possible benefits and limitations in the context of Serbia. The first part of the article introduces a global background of the problem of climate adaptation, summarising major environmental trends, research problems and policy responses, and emphasising the relation between climate change and urban(ised) environment. The second part is dedicated to the case of Serbia, focusing on three aspects - general condition of the environment, the legal framework and the perception/recognition of urban context and its environmental effects in recent development documents. The third part is focused on the relation between information networks, built environment/ cities and climate changes, providing an overview of global trends and Serbian practice, while possible improvements of detected local weaknesses are given in the concluding part.

ALEKSANDRA STUPAR; B.Arch, MSc, PhD.

Currently works as an associate professor at the University of Belgrade, Faculty of Architecture, where she graduated and obtained her MSc (2001) and PhD (2005) degrees. Major research interests include technological, environmental and cultural aspects of contemporary cities. Also the winner of Gerd Albers Award 2008, given by ISOCARP for the best published article on urbanism. stupar@afrodita.rcub.bg.ac.rs

VLADIMIR MIHAJLOV; B.Arch, MSc, PhD.

Received his M.Sc in Urban Design, Planning and Management (1995-2002) in Department of Urbanism at Faculty of Architecture, University of Belgrade. Earned his PhD degree in Urban planning in 2011. Currently works as an assistant professor at the University of Belgrade, Faculty of Architecture. Major research interests include studying the methodology of projects and urban plans evaluation. mihajlovvladimir@yahoo.com 